\title{
REMOTE SENSING TERTIARY EDUCATION MEETS HIGH INTENSITY INTERVAL TRAINING
}

\author{
K.E. Joyce ${ }^{\mathrm{a} *}$ and B. White ${ }^{\mathrm{b}}$ \\ ${ }^{a}$ Research Institute for the Environment and Livelihoods, Charles Darwin University. Ellengowan Road, Darwin, NT 0810 Australia \\ karen.joyce@cdu.edu.au \\ ${ }^{\mathrm{b}}$ School of Engineering and Information Technology, Charles Darwin University. Ellengowan Road, Darwin, NT 0810 Australia \\ barbara.white@cdu.edu.au
}

KEY WORDS: education, active learning, online resources, remote sensing, student centred, choreography

\begin{abstract}
:
Enduring a traditional lecture is the tertiary education equivalent of a long, slow, jog. There are certainly some educational benefits if the student is able to maintain concentration, but they are just as likely to get caught napping and fall off the back end of the treadmill. Alternatively, a pre-choreographed interactive workshop style class requires students to continually engage with the materials. Appropriately timed breaks or intervals allow students to recover briefly before being increasingly challenged throughout the class. Using an introductory remote sensing class at Charles Darwin University, this case study presents a transition from the traditional stand and deliver style lecture to an active student-led learning experience. The class is taught at undergraduate and postgraduate levels, with both on-campus as well as online distance learning students. Based on the concept that active engagement in learning materials promotes 'stickiness' of subject matter, the remote sensing class was re-designed to encourage an active style of learning. Critically, class content was reviewed to identify the key learning outcomes for the students. This resulted in a necessary sacrifice of topic range for depth of understanding. Graduates of the class reported high levels of enthusiasm for the materials, and the style in which the class was taught. This paper details a number of techniques that were used to engage students in active and problem based learning throughout the semester. It suggests a number of freely available tools that academics in remote sensing and related fields can readily incorporate into their teaching portfolios. Moreover, it shows how simple it can be to provide a far more enjoyable and effective learning experience for students than the one dimensional lecture.
\end{abstract}

\section{BACKGROUND}

\subsection{The setting}

This is told from the perspective of lead author, Karen Joyce.

In my fifth year teaching the introductory remote sensing unit, student numbers had more than tripled. My student evaluation scores were consistently above average. Student feedback was always positive. So there was nothing wrong with this class. But with the standard two hour lecture and three hour practical format, it was in danger of becoming stale, if not for the students, certainly for me. I was aware that something needed to change.

In my parallel life, I am a group fitness instructor. I teach high intensity interval training (HIIT), which is known to be the fastest, most efficient way to get fit. I wanted to know if I could use this fitness concept in my undergraduate and postgraduate classes. Remote sensing tertiary education meets high intensity interval training? The fastest, most efficient way to learn.

High intensity interval training focuses on short to moderate bursts of quality energy expenditure, followed by recovery intervals (Laursen and Jenkins 2002). To map my remote sensing class learning outcomes to this mode of activity, it was critical to focus on quality learning occurring over shorter, sharper periods rather than the traditional single paced two-hour lecture.

\subsection{The challenge}

It was challenging to review my previous lecture materials and really consider the key learning objectives. I had to sacrifice significant content quantity for what I now believe is learning quality. This content review changed the focus of the class to one of deep learning (Fullan and Langworthy 2014). As a product of a generation who attended hours of lectures expecting to passively absorb huge volumes of knowledge, some parts of me really struggled to let go of this delivery style. I felt like I might be neglecting my responsibility to expose the students to all the concepts, terms, and theories. Then I came to accept that exposure is nothing if these things are not remembered or understood. But experiences count.

\section{APPROACH}

In my role as a group fitness instructor, I act as a coach for the class. I move between my members, offering advice, and challenging some individuals while holding back with others dependent on their fitness level. I wanted to incorporate this coaching style instead of delivering a lecture. I realised that to spend more time interacting with the students, I would need to change my perspective. The key - don't attempt to do everything, and instead reduce the breadth while increasing the depth. To achieve this, I removed the somewhat boring, theoretically based material from class time, and asked my students do this before class, following a 'flipped classroom' structure (Fulton 2012). But this wasn't about requiring students to read a textbook chapter. I developed a range of

* Corresponding author 
online interactive resources so they could learn in their own time, at their own pace (e.g. Joyce et al. 2014). They then came to class armed with some base knowledge of the topics for the week. As in incentive to complete the materials, a small portion of the unit grade was allocated to a 'reasonable' attempt. Additionally, students would find the class work considerably more difficult if they hadn't done the pre-class work. This ensured a high completion rate. The pre-class work had the added advantage of allowing me to identify areas where students were struggling or had misunderstood the content. I could then address any deficiencies immediately in class.

To change my lecture into something more akin to my group fitness style, I developed a series of activities for the students to work through. I even choreographed the session, just like a group fitness class. There was a warm up - a simple, confidence building activity. As the class progressed, the activities became harder and more intense. The class concluded with a reflective activity or a cool down period.

An example of class 'choreography' is given in Appendix 1. Different phases of the class were identified alongside the required timing. The learning objective (student perspective) and instructor intent is also given for each activity associated with different stages within the class. Finally, a traffic light colour system was shown to demonstrate the 'mental intensity' of the activity for the students. Here the intent was to alternate high intensity (red) with moderate, or low intensity activities. This creates the interval style similar to fitness training. Note that this plan was for the instructor only, and not disseminated to the students.

Students were surveyed mid-way through semester, and again at the end of the semester. They were asked to comment on a number of questions relating to their overall learning experience and satisfaction with the way in which the class was taught.

\section{RESOURCES}

Several key online resources provide the foundation for the learning materials in this class (see Appendix 2 for complete listing). Principally, the Remote Sensing Computer Aided Learning Program (RSCAL) is an interactive resource with modules and topics similar to a generic remote sensing hard copy textbook (Joyce et al. 2014). The Remote Sensing Virtual $\mathrm{Lab}$ then extends these concepts, focussing more on the practical side of remote sensing such as using a field spectrometer. A 'choose your own adventure' style fable about using remote sensing to detect coral bleaching was used to engage students in problem based learning in a real-world scenario. And finally a wealth of theory and practical related videos were available on the related class YouTube channel. Each of these resources adhered to the concept of creating a depth of understanding within multiple relatively short 'intervals'. Many other supplementary online tools were used to encourage collaboration within the class.

\section{RESULTS}

During class, I walked an average of over $700 \mathrm{~m}$ as I moved between students and groups, demonstrating that this was certainly not a static traditional lecture style. No two weeks were the same, though all had some aspect of peer or group learning. Class activities revolved around solving real remote sensing challenges using interactive learning techniques including speed-dating, debates, mind-mapping, and brainstorming.

My class was noisy. Students had an increased level of confidence in expressing their ideas, and asking questions. I never experienced the uncomfortable silence to an unanswered question. And at the end of the class - I had to kick them out! They didn't want to leave. This I found to be the most satisfying part.

Throughout the semester I gained a renewed sense of energy from and for teaching, or coaching in this way. Every week I challenged myself to come up with an interesting and engaging way for students to work on a problem to achieve a learning outcome. It's the experiences that count, and I wanted my students to experience remote sensing and all that it encompasses.

\subsection{Student feedback}

From the mid-term student survey, it was clear that students were very happy with this style of teaching. In particular, the 'flipped classroom' formula was working very well to keep students engaged with the materials on a weekly basis. A selection of student comments are given below.

"I would recommend this style of lecturing to be introduced to many other lecturers so that both the lecturer and future students would benefit from the 'comradery' and collaboration between lecturer and students resulting from this style of teaching"

"Going by other subjects I've done at CDU and other institutions this one has taken me by surprise. I wasn't expecting remote sensing to be such an engaging subject. I'm impressed with the dedication to genuinely producing an all round learning environment - it's so rare to see in practice. I've learnt a lot from just the teaching framework and style - let alone the content. I appreciate the amount of work which must go into pulling everything together. Definitely got value for time and money here. Thank you!!"

"This unit was impressive in its organisation and use of a range of communication media that it's difficult to offer suggestions for improvements. In fact it sets an extremely high benchmark"

"An approach which builds discipline to studying a new subject area - e.g. regular revision, theory matched with practical application, questioning and relating new information to existing knowledge, explaining concepts using simplified but relevant analogies as well as organising and giving structure to an analytical process"

"This unit is very engaging. It has a comfortable environment where I am able to learn without a whole lot of added stress. All the topics discussed are of interest to me and I find things like 'the picture of the week' intriguing and engaging also"

\section{CONCLUSIONS AND FUTURE WORK}

The concept of high intensity interval training presented within a university lecture environment was tested in an introductory remote sensing class. Students and staff reported positively on the experience, which is now presented here to provoke ideas 
and inspire others to approach tertiary education from a new perspective.

The work contained herein represents the culmination of many years of unknowing preparation. The preparation was not necessarily directly to teach in this style, but to create all of the supporting material that has made the class unique. Online resources such as the Virtual Lab and RSCAL were instrumental in implementing the flipped classroom format. With these resources now freely available, they can now be used by academics around the world to support them teaching in a similarly interactive manner.

We encourage academics from a range of discipline areas to try the model and report their experiences. It is crucial to experiment within a supportive environment of other staff members and we recommend creating a community of practise to achieve this.

\section{ACKNOWLEDGEMENTS}

We gratefully acknowledge the collective contribution and support from the Faculty iScholar team and partners for providing the environment to innovate.

\section{REFERENCES}

Fullan, M., \& Langworthy, M. (2014). A rich seam: How new pedagogies find deep learning. London: Pearson

Fulton, K. (2012). Upside down and inside out: Flip your classroom to improve student learning. Learning and Leading with Technology, 39, 12-17

Joyce, K.E., Boitshwarelo, B., Phinn, S.R., Hill, G.J.E., \& Kelly, G.D. (2014). Interactive online tools for enhancing student learning experiences in remote sensing. Journal of Geography in Higher Education, 38, 431-439

Laursen, P.B., \& Jenkins, D.G. (2002). The Scientific Basis for High-Intensity Interval Training. Sports Medicine, 32, 5373

\section{APPENDICES}

1. An example of class choreography from Week 2 in the Introductory Remote Sensing class. MI = 'mental intensity' where green is easy, orange is moderate, and red is challenging. Note in particular the use of several online tools to encourage interaction - video, RSCAL, UCROO, QR codes, Scoopit, and Padlet. See Appendix 2 for a description and location of these tools.

\begin{tabular}{|c|c|c|c|c|c|}
\hline Phase & Time & Learning Objective & Instructor Intent & Activity & MI \\
\hline Pre-class & & $\begin{array}{l}\text { To get into the routine of } \\
\text { pre-class activities }\end{array}$ & $\begin{array}{l}\text { Get students to hear new } \\
\text { terminology }\end{array}$ & $\begin{array}{l}\text { Video - Bernie Hobbs EMR, RSCAL } \\
\text { module }\end{array}$ & \\
\hline Warm-up & 9:00 & $\begin{array}{l}\text { To start to get the feel of } \\
\text { satellite imagery }\end{array}$ & $\begin{array}{l}\text { Something to discuss as } \\
\text { students are walking in }\end{array}$ & $\begin{array}{l}\text { Image of the week - post image onto } \\
\text { UCROO just prior to class }\end{array}$ & \\
\hline "'Revision & $9: 10$ & $\begin{array}{l}\text { To build on the } \\
\text { foundation of class } \\
\text { networks }\end{array}$ & $\begin{array}{l}\text { Get students comfortable } \\
\text { with each other to start } \\
\text { opening the lines of } \\
\text { communication } \\
\text { collaboration }\end{array}$ & $\begin{array}{l}\text { Treasure hunt in groups using QR codes. } \\
\text { Find as many as they can, then select one } \\
\text { to review and report back on. Five mins } \\
\text { each to find, review, and report on } \\
\text { Scoopit }\end{array}$ & \\
\hline \multirow[t]{3}{*}{ Explore } & $9: 25$ & $\begin{array}{l}\text { To understand the basics } \\
\text { of wave and practical } \\
\text { theory and its application } \\
\text { for remote sensing }\end{array}$ & $\begin{array}{l}\text { To draw out the key points } \\
\text { of how theory relates to our } \\
\text { remote sensing } \\
\text { observations }\end{array}$ & $\begin{array}{l}\text { Theory - interactive talk: Wave and } \\
\text { particle / } \\
\text { Conservation of energy }\end{array}$ & \\
\hline & $9: 40$ & $\begin{array}{l}\text { To understand the } \\
\text { physical nature of energy } \\
\text { interactions }\end{array}$ & $\begin{array}{l}\text { To lighten the mood, whilst } \\
\text { doing } \\
\text { memorable }\end{array}$ & $\begin{array}{l}\text { Role play energy interactions - reflect, } \\
\text { absorb, transmit, scatter }\end{array}$ & \\
\hline & $9: 45$ & $\begin{array}{l}\text { To further understand the } \\
\text { role of reflection, } \\
\text { absorption, and scattering } \\
\text { in the environment }\end{array}$ & $\begin{array}{l}\text { To bring students back into } \\
\text { learning mode, and discuss } \\
\text { key interactions }\end{array}$ & $\begin{array}{l}\text { Theory: EMR interactions and } \\
\text { atmospheric windows }\end{array}$ & \\
\hline $\begin{array}{l}\text { Apply \& } \\
\text { Understand }\end{array}$ & $10: 10$ & $\begin{array}{l}\text { To understand the types } \\
\text { of features that will } \\
\text { reflect, absorb, transmit, } \\
\text { reflect, and scatter light }\end{array}$ & $\begin{array}{l}\text { Get students comfortable } \\
\text { with the concept of } \\
\text { different interactions }\end{array}$ & $\begin{array}{l}\text { Laminated printout of conceptual } \\
\text { diagram of an environment. In pairs, } \\
\text { students draw arrows with different } \\
\text { colours to show energy interactions. } \\
\text { Pairs then discuss with another pair to } \\
\text { compare ideas }\end{array}$ & \\
\hline $\begin{array}{l}\text { Student } \\
\text { Choice }\end{array}$ & $10: 35$ & $\begin{array}{l}\text { To clearly understand the } \\
\text { difference between GIS } \\
\text { and remote sensing, and } \\
\text { how they may be } \\
\text { integrated }\end{array}$ & $\begin{array}{l}\text { Draw out the concepts of } \\
\text { 'system' in GIS, which } \\
\text { means people, software, } \\
\text { hardware, data, methods. } \\
\text { GIS is always spatial, } \\
\text { remote sensing not } \\
\text { necessarily }\end{array}$ & $\begin{array}{l}\text { What is the difference between GIS and } \\
\text { Remote Sensing? Brainstorm first what is } \\
\text { remote sensing, and then GIS ideas on } \\
\text { Padlet. Class discussion on how remote } \\
\text { sensing can be incorporated into GIS }\end{array}$ & \\
\hline Reflection & $10: 50$ & $\begin{array}{l}\text { To revise main points } \\
\text { from the lecture }\end{array}$ & $\begin{array}{l}\text { Pause and allow some of } \\
\text { the content to sink in, and } \\
\text { to highlight areas of } \\
\text { uncertainty to follow up on }\end{array}$ & $\begin{array}{l}\text { Use Padlet to post something that } \\
\text { students learnt and something they are } \\
\text { unsure about }\end{array}$ & \\
\hline Wrap up & $10: 55$ & & & Tidy classroom & \\
\hline
\end{tabular}


2. Online tools used throughout the semester to support student learning. All are freely available unless otherwise noted.

\begin{tabular}{|c|c|c|}
\hline Tool & Description / Use & Location \\
\hline UCROO & $\begin{array}{l}\text { 'Facebook' like interface, used for posting links to interesting } \\
\text { materials, class reflections, discussions, image of the week } \\
\text { contest, technical support, and all non-confidential student } \\
\text { queries }\end{array}$ & http://www.ucroo.com.au/ \\
\hline RSCAL & $\begin{array}{l}\text { Remote Sensing Computer Aided Learning program - } \\
\text { interactive textbook for foundational remote sensing } \\
\text { information }\end{array}$ & http://kejoyce.com/education \\
\hline $\begin{array}{l}\text { Remote Sensing } \\
\text { Virtual Lab }\end{array}$ & $\begin{array}{l}\text { Interactive learning focussed on the more practical side of } \\
\text { remote sensing }\end{array}$ & http://remotesensinglab.com \\
\hline $\begin{array}{l}\text { Remote sensing } \\
\text { investigation - mass } \\
\text { coral bleaching }\end{array}$ & $\begin{array}{l}\text { Problem based learning fable, written in a 'choose your own } \\
\text { adventure' style }\end{array}$ & http://kejoyce.com/education \\
\hline Padlet & $\begin{array}{l}\text { Blank canvas where students can post their thoughts or } \\
\text { reflections on a particular set topic }\end{array}$ & http://padlet.com \\
\hline YouTube & $\begin{array}{l}\text { Hosting all educational videos including lecture recordings, } \\
\text { short 'snippets' of theory content, animations, and software } \\
\text { demonstrations }\end{array}$ & https://www.youtube.com/user/kejoyce12 \\
\hline QRstuff & $\begin{array}{l}\text { QR code generator - used for a 'treasure hunt' around the } \\
\text { classroom. Each code is generated for a website of relevance to } \\
\text { the classwork, that students then need to comment on }\end{array}$ & http://www.qrstuff.com/ \\
\hline Tagxedo & Creating word clouds from student surveys & http://www.tagxedo.com/ \\
\hline Answer Garden & $\begin{array}{l}\text { An interactive word cloud generator, great for quick student } \\
\text { feedback }\end{array}$ & http://answergarden.ch/ \\
\hline Scoopit & $\begin{array}{l}\text { Curating tool where students can post comments about } \\
\text { different 'scooped' topics }\end{array}$ & http://scoop.it \\
\hline MindMapFree & Mind mapping - used to create an image interpretation key & http://mindmapfree.com/ \\
\hline Sparkol VideoScribe & $\begin{array}{l}\text { Great for creating short whiteboard style animations to explain } \\
\text { certain concepts, either by instructor or student. Short free trial } \\
\text { or paid subscriptions }\end{array}$ & http://www.videoscribe.co/ \\
\hline GoAnimate & For creating animated cartoons. Free with limited functionality & http://goanimate.com/ \\
\hline Pixton & For creating cartoon strips & http://www.pixton.com/uk/ \\
\hline Weebly & $\begin{array}{l}\text { Website creation and hosting interface. Used as the student } \\
\text { portal to all class materials }\end{array}$ & http://weebly.com \\
\hline Today's Meet & Back channel used for student note taking & https://todaysmeet.com/ \\
\hline
\end{tabular}

